wo die $C_{\alpha}$ beständig convergente Potenzreihen in $n^{2}$ und von $m$ und $\beta$ unabhängig sind. Zur Ermittelung der $C$ kann man unter Berücksichtigung von (9) die Gleichung verwenden, welche man aus ( 10 ) erhält, wenn man für $m$ irgend einen speciellen Werth, z. B. $m=0$ oder $m=n$ setzt. Ein anderer Weg besteht darin, dass man auf irgend eine Weise aus der ursprünglichen Differentialgleichung die Reihenentwickelung der Wurzel $m$ nach $\beta$ direct herleitet und in die Bedingung $f(\boldsymbol{m})=0$ substituirt. Da ich auf diesen Gegenstand bei einer späteren Gelegenheit wieder zurickkommen will, so beschränke ich mich hier auf die Betherkung, dass die $C$ sich in der Forn:

$$
F \cos 2 \pi n+G \sin 2 \pi n
$$

darstellen lassen, wo die $F$ und $G$ rationale Functionen von $n$ sind, in deren Nennern nur Linearfactoren von der Form $2 n+$ ganze Zahl auftreten.

Leipzig $\times 883$ Juli 20.

Filar-Micrometer Observations of Comet 1883 I (Brooks) made with the thirteen-inch Equatoreal of the Dudley Obserratory.

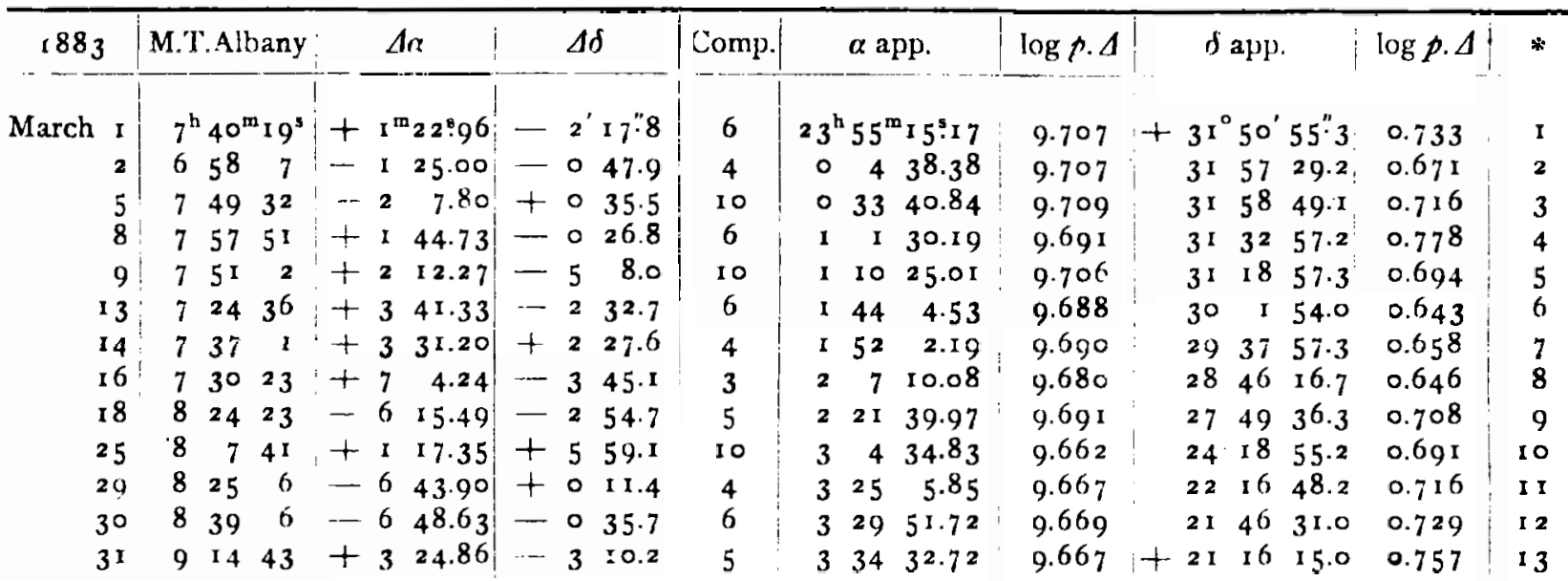

Each comparison in Right-Ascension is the mean of three wires on both comet and stirr. Corrections for Differential Refraction have been applied.

Mean places of comparisonstars for 1883.0.

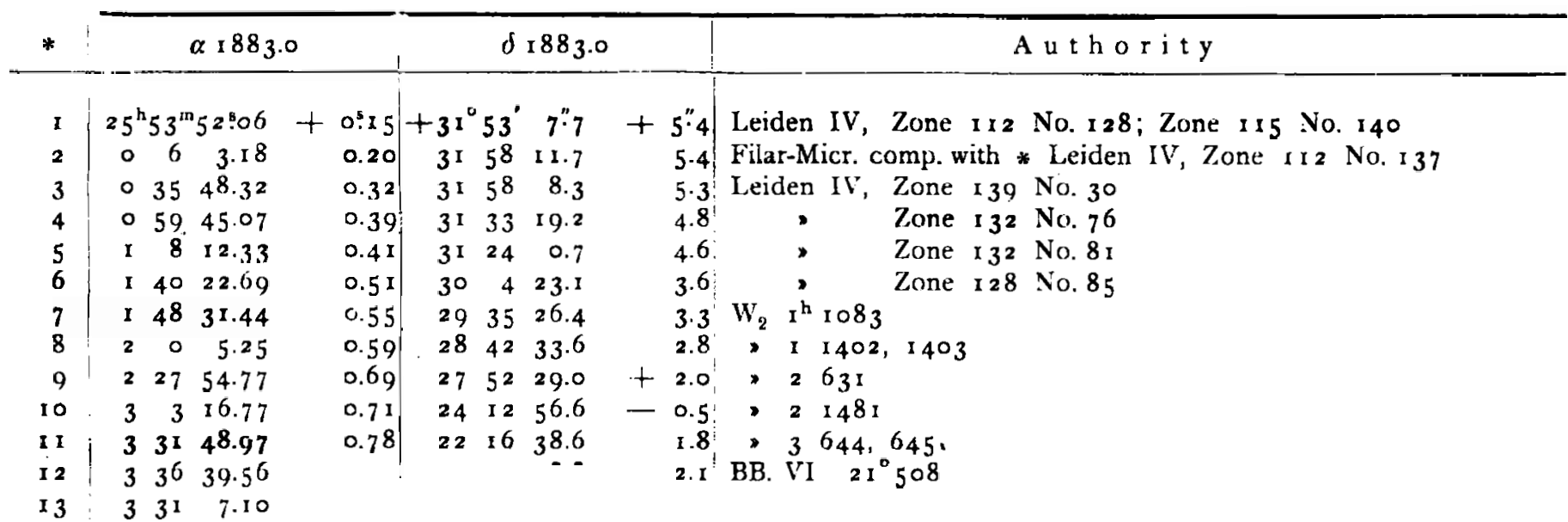


From a late and more complete determination of the value of one revolution of the micrometer, by $\mathrm{Mr}$. $\mathrm{H}$. V. Egbert, there result the following corrections to the Declinations of the series of observations of the Great Comet of I882, published in A. N. Nr. 2502.

$$
\text { Oct. } \begin{array}{r}
1-1.2 \\
3+0.4 \\
7-1.5 \\
8-0.2 \\
9+2.2 \\
14+0.6 \\
15-2.1 \\
19-2.6 \\
20-0.4 \\
24-1.9
\end{array}
$$

\begin{tabular}{|c|c|c|c|c|c|}
\hline 1882 & Étoile & Gr. & $\begin{array}{l}\text { Dispar. } \\
\text { t. m. de }\end{array}$ & $\begin{array}{l}\text { Réappar. } \\
\text { Tachkent }\end{array}$ & Remarques \\
\hline Sept. 26 & $\lambda$ Piscium & 5 & $6^{\mathrm{h}} 33^{\mathrm{m}} 40^{\mathrm{s}} 4^{*}$ & _ & Bonne. \\
\hline Oct. $\quad 2$ & $\chi^{1}$ Orionis & $4^{1 / 2}$ & $165^{6} 44 \cdot 3^{*}$ & - & Bonne. \\
\hline 15 & $\lambda$ Librae & 6 & 61056.2 & - & [deuxième bonne. \\
\hline Nov. 2 & 60 Cancri & 6 & II $514.0^{*}$ & $12^{h} 49^{m} 18: 2$ & La première observation n'est pas tout à fait exacte; la \\
\hline $\begin{array}{l}17 \\
20\end{array}$ & $\begin{array}{l}v \text { A Aluarii } \\
22 \text { Piscium }\end{array}$ & $\begin{array}{l}4^{1 / 2} \\
6\end{array}$ & $\begin{array}{rrr}6 & 29 & 29.3 \\
6 & 18 & 2.2\end{array}$ & $733 \quad 0.5^{*}$ & Toutes les deux observations sont bonnes. \\
\hline 26 & $\chi^{2}$ Orionis & $\begin{array}{l}6 \\
6\end{array}$ & $\begin{array}{rrrr}0 & 18 & 2.2 \\
12 & 2 & 59 \cdot 5^{*}\end{array}$ & 125942.5 & $\begin{array}{l}\text { Bonne. } \\
\text { La première observ. n'est pas exacte; la deuxième est }\end{array}$ \\
\hline 29 & B.A.C. 2872 & 6 & - & $1025 \quad 27.2$ & Très-bonne. \\
\hline 30 & (1) Leonis & 6 & $125837.5^{*}$ & $14 \times 6 \quad 2.4$ & Toutes les deux observations sont bonnes. \\
\hline Déc. I 7 & ${ }_{5} 5$ Piscium & $61 / 9$ & $45 \times 13.2$ & - & Très-bonne. \\
\hline
\end{tabular}

Dudley Observatory, Albany, ${ }_{2} 88_{3}$ Aug. 2.

$$
\begin{array}{rr}
\text { Oct. } 26-0.1 \\
27+5.4 \\
30+3.0 \\
\text { Nov. } 27-2.3 \\
4+1.0 \\
5-0.4 \\
10-0.4 \\
13+0.5 \\
18-1.7 \\
19+2.5
\end{array}
$$

\section{Observations des occultations des étoiles faites à l'Observatoire de Tachkent.}

Par M. Zalessky.

Instrument: lunette de Fraunhofer; ouvert. de l'object. $77^{\mathrm{mm}} ;$ dist. focale $\mathrm{I}^{\mathrm{m}} \mathbf{2 0} ;$ grossissement 70 .

* signifie que le phénomène était observé sur le bord éclairé de la lune.

\section{A convenient method of finding or identifying an Asteroid.}

The following method I have never seen noticed and is rapid in its use. The means to be employed are a micrometer and a sheet of cross-section paper.

Let the micrometer be light and furnished with an accurate but somewhat coarse screw for quick motion.

Also let the screw head be divided in the ordinary way for fractional parts of a revolution. The usual graduated position circle is unnecessary. The micrometer plate itself carrying the spider lines is to be capable of a revolution through $90^{\circ}$ upon its tube, at the same time being prevented from further motion by stops.

Having adjusted the micrometer to the telescope and brought the region of the asteroid into the field, turn the micrometer plate until it abats against one of the stops, and, with it in this position, turn the whole micrometer, by the position circle of the telescope itself or rotation of the entire tube, until one of the spider lines coincides accurately with a parallel of declination.

Having selected a convenient star and attached the driving clock, measure with the micrometer screw the difference of Right-Ascension and Declination of each object in the field from it, bringing the plate alternately against each stop. In this way a rapid determination of relative position of all objects in the field may be made in both coördinates. 